\title{
Managers in the transformation process of Eastern Europe - A case of Slovenia ${ }^{*}$
}

\author{
Danijel Pucko / Matej Lahovnik ${ }^{* *}$
}

The article offers results of the empirical research project on strategic restructuring processes in Slovenian enterprises. The changes in the positions of managing directors of enterprises and developments of the value systems and objectives of Slovenian managers are discussed. The authors show a comparison of the relevant values and objectives of Slovene managers and their Western European counterparts. They briefly describe the differencies between both groups of managers. The research has tried to identify the managing directors' perception of the competitive advantage's factors and the business strategies that are being implemented in the Slovenian enterprises. Finally, the managing directors' assessments of the length of the strategic restructuring process in the Slovenian "old" firms are presented.

Der Artikel handelt von den Änderungen in den Führungspositionen der "ehemaligen" slowenischen Firmen, der Entwicklung des Bewertungssystems und den Zielen der slowenischen Geschäftsführer. Es folgt eine Gegenüberstellung der relevanten Bewertungen und Ziele zwischen den slowenischen und westeuropäischen Geschäftsführern, wobei die Unterschiede zwischen den beiden Geschäftsführergruppen aufgezeigt werden. Weiter wird ein Vergleich gezogen zwischen den Konkurrenzfaktoren, die als das wichtigste Element des strategischen Handelns bezeichnet werden können. Außerdem werden die Geschäftsstrategien beschrieben, die in den slowenischen Firmen umgesetzt worden sind. Abschließend wird eine Prognose über die Dauer der strategischen Umstrukturierungsprozesse abgegeben.

Manuscript received: 24.4.97, accepted: 19.9.97

** Danijel Pucko , born 1944, PhD., Professor at the Faculty of Economics, University of Ljubljana. His main professional field of interest is Strategic Management, Business Planning and Business Economics.

Mail address: University of Ljubljana, Faculty of Economics, Kardeljeva ploscad 17, 1000 Ljubljana, Slovenia

Email: daniel.pucko@uni-lj.si

Matej Lahovnik, born 1971, Assistant teacher at the Faculty of Economics, University of Ljubljana. 


\section{Introduction}

Slovenia established a democratic political system in 1990. It became a new, independent European state in 1991 when the Socialist Republic of Yugoslavia split apart. Slovenian businesses lost a relatively huge domestic market as a result of all these changes. It could be argued that the country has been in transition since 1990. Political and economic reforms have been present in the country since the time when new political parties seized power in Spring, since 1990. The transition in Slovenia has been going on for six years. The privatisation process of former "social" enterprises (self-managing business firms) started to be implemented in 1994. The great majority of "social" enterprises have already been privatised.

The majority of enterprises that already existed before the transition period have been forced to strategically restructure themselves because of radical changes which have taken place in their environment. In more than two thirds of the enterprises the restructuring processes are not completed yet. These processes are lead by managing directors of businesses and by top management teams. The analysis is to focus on six key issues: firstly the changes which have taken place in the positions of the managing directors of enterprises; secondly, the developments which have taken place in the value systems of managing directors and senior managers; thirdly the personal objectives of these executives, and fourthly, their objectives as employers. The values and objectives of the Slovenian managers are compared with those of Western European managers. As values and personal objectives influence enterprises' strategic objectives and the managing directors' perception of the competitive advantage's factors, we intend to identify the stated variables and offer some relevant empirical findings. As business units try to achieve their competitive advantages through the use of business strategy, business strategies of the Slovenian enterprises are presented. Finally, we asked the Slovenian managers to analyze the current situation and to predict the length of the process of strategic restructuring in Slovenian enterprises.

On the one hand our research was based on the theoretical examination of the managers' position in the transformation process (Kilmann et al., 1988) and phenomenon of strategic restructuring of an enterprise (Brilmann, 1986) and on the other hand on an extensive questionnaire. Managing directors or members of the management teams of Slovenian enterprises were asked to respond to the questions in the questionnaire. The empirical research was limited to five strongest manufacturing industries (metal and metal products, electrical and optical equipment, chemical, textile and garment, and food processing) in Slovenia, which were selected according to their shares in the creation of GNP in 1990. We excluded small enterprises from our sample (i.e. enterprises with less than 125 employees). All the enterprises included in the sample had to meet one requirement, which was, that they had been founded before 1990. New 
enterprises, which were founded during the transition period, were of no research interest to us. Our assumption was that only old enterprises needed strategic restructuring.

In the 1994 survey 64 enterprises out of 250, which existed in the mentioned five industries and which met the requirement, responded (Pucko, 1995, No.56). The 1996 survey was based on the same criteria. Some undergraduate and graduate students of the Faculty of Economics in Ljubljana collected answers to our questionnaire from 80 enterprises.

Out of 80 enterprises, which co-operated in the research, $59.5 \%$ are incorporated, $34.2 \%$ are limited companies, the rest has some other legal status. The majority of responding enterprises has a mixed ownership (38\%), 31.6\% enterprises are privately owned, and $26.6 \%$ are still social companies (selfmanaging firms). The rest is owned by the Development Fund of the Republic of Slovenia or by the state.

\section{Managing directors as leaders of strategic restructuring of enterprises}

The research results show that $51.3 \%$ of all managing directors have held their positions from the eighties. One quarter of managing directors (25.6\%) took over their positions in the 1990-1991 period. About a quarter of managing directors $(23.1 \%)$ have got these positions in the last three years. The stated shares support the thesis that there have been no major politically motivated changes at the level of managing directors in firms. It is quite logical (Kilmann et al., 1988) that many more new managing directors have been nominated to their positions in those enterprises that have met with some type of crisis than in those enterprises that have not experienced serious economic difficulties in the transition period. (See Table 1.) As the number of responses to that particular question was higher in the 1994 research, and as there are significant differences in findings, the results of the larger sample (e.g. from 1994) should be more reliable.

Age distribution of managing directors could not be assessed as a bad one. 7.7\% of managing directors are younger than 36. Most managing directors belong to the age bracket between 46 and 55 years (53.8\%), which is certainly an age that still allows for creativity and serious contributions to company development. Their life working time horizon is still long enough that they are motivated to create vision for their company and to take over needed business risk in implementing it. 28.2\% of managing directors are in the age bracket between 36 and 45 years. They are still young, but usually well educated. Modest management education and experience might be a possible weakness for the majority of Slovenian managers. Of course, our conclusions should not be too 
firm as we have not been researched into the Slovenian top management talents and skills.

Table 1: How long does a managing director hold his/her position in a company according to the 1994 and 1996 researches

\begin{tabular}{|c|c|c|c|c|c|c|}
\hline \multirow[b]{2}{*}{$\begin{array}{l}\text { Period } \\
\text { Company } \\
\text { performance }\end{array}$} & \multicolumn{3}{|c|}{ Research in 1994} & \multicolumn{3}{|c|}{ Research in 1996} \\
\hline & $\begin{array}{c}\text { Managing } \\
\text { director } \\
\text { holding his } \\
\text { position } \\
\text { already } \\
\text { before } 1990\end{array}$ & $\begin{array}{l}\text { A new } \\
\text { managing } \\
\text { director in } \\
\text { the period of } \\
\text { transition }\end{array}$ & Total & $\begin{array}{l}\text { Managing } \\
\text { director } \\
\text { holding his } \\
\text { position } \\
\text { already before } \\
1990\end{array}$ & $\begin{array}{l}\text { A new } \\
\text { managing } \\
\text { director in } \\
\text { the period } \\
\text { of } \\
\text { transition }\end{array}$ & Total \\
\hline Good & 15 & 17 & 32 & 16 & 13 & 29 \\
\hline Not good & 5 & 21 & 26 & 4 & 6 & 10 \\
\hline Total: & & & & & & \\
\hline Number & 20 & 38 & 58 & 20 & 19 & 39 \\
\hline$\%$ & 34.5 & 65.5 & 100.0 & 51.2 & 48.8 & 100.0 \\
\hline
\end{tabular}

How do managing directors perceive their key tasks within the processes of strategic restructuring of their enterprises? Most managing directors consider that over the period of the next three years their most important tasks will be linked to cost reduction (32.5\%), search for new markets (32.5\%), introduction of total quality concepts into their firms (30\%), and many others. (See Table 2.) Comparing the perception of the key tasks as found in the 1994 research with the stated one, some significant differences could be noticed. Nowadays there are many more enterprises that have a very well defined strategy, more or less settled personnel issues (managerial and staff), clear plans regarding their future development with regard to the product range (Goold, 1996), and have already implemented the needed organisational changes. Therefore, it seems that their key tasks (let us assume that we deal with the second stage in the process of strategic restructuring of enterprises within the framework of transition) are becoming linked to cost reduction, quality, and market development.

Key tasks should have some connection with the most difficult problems, which managing directors have to solve. Let us find out, therefore, which have been those problems according to the managing directors' perceptions in the last three years. Privatisation (27.5\% of managing directors), finding substitute sales markets (22.5\%), cost reduction (21.3\%), enterprise reorganisation $(21.3 \%)$, reduction of labour force (21.3\%), financial consolidation of enterprise (18.8\%), and restructuring company product range (16.3\%) are identified as the toughest problems that managing directors have dealt with in the second phase (1994 1996) of the transition process in Slovenia. Comparing those problems with the 
ones that were most frequently mentioned in the 1994 research, we may argue that in the first phase of the transition process the problems of appropriate human resources, labour force reduction, and product range restructuring were far more pronounced than in the last three years.

Table 2: Managing director's key tasks in the strategic management process in the next three years

\begin{tabular}{|c|c|c|}
\hline Managing director's key tasks & $\begin{array}{l}\% \text { of managing directors according } \\
\text { to the } 1994 \text { research }\end{array}$ & $\begin{array}{l}\% \text { of managing directors according } \\
\text { to the } 1996 \text { research }\end{array}$ \\
\hline Formulating a new strategy & 34.4 & 17.5 \\
\hline $\begin{array}{l}\text { Recruitment and develop- } \\
\text { ment of personnel }\end{array}$ & 28.1 & 18.8 \\
\hline Product development & 21.9 & 14.0 \\
\hline Market development & 21.9 & 32.5 \\
\hline Organisational changes & 21.9 & 10.0 \\
\hline Privatisation & 20.3 & $\ldots$ \\
\hline Cost reduction & 20.3 & 32.5 \\
\hline Team building & 12.5 & ... \\
\hline Quality & 10.9 & 30.0 \\
\hline $\begin{array}{l}\text { Strategy implementation and } \\
\text { follow - up }\end{array}$ & 10.9 & ... \\
\hline
\end{tabular}

\section{Personal values and attitudes held by the Slovenian top managers}

The managing directors' values have been changing slowly and insignificantly in the transition period (See Table 3 and 6). They still differ noticeably from the value systems of Western European entrepreneurs and managers. Comparison with the research results of the STRATOS joint research project (The STRATOS Group, 1990: 27 and 36) proves this fact.

The most important personal value held by the Slovenian top managers is obviously the statement that "a firm should enter foreign markets". Western European managers in small countries assigned only 3.74 mean-weighted score to this value. The reason for such result is that Slovenian firms have a relatively small domestic market nowadays. In the past Slovenian economy achieved 24.8\% of its total sales on the markets of former Yugoslavia. The share of total sales to Eastern European markets was lower than 5\% compared to $17.9 \%$ on the hard currency markets (Regionalna struktura,1991). Radical changes on the 
domestic and Eastern European markets forced Slovenian enterprises into restructuring their sales markets. At first this task seemed nearly unattainable, at least in the short run. Enterprises were first implementing the restructuring of their sales market by strengthening their sales on the small Slovenian market (i.e. new domestic market). Later those firms, which enjoyed the biggest shares of sales on the Slovenian market, gradually started to acquire substitute markets. (See Table 4.) They have reached some apparent achievements in this field.

Table 3: The most important personal values and attitudes held by the Slovenian top managers

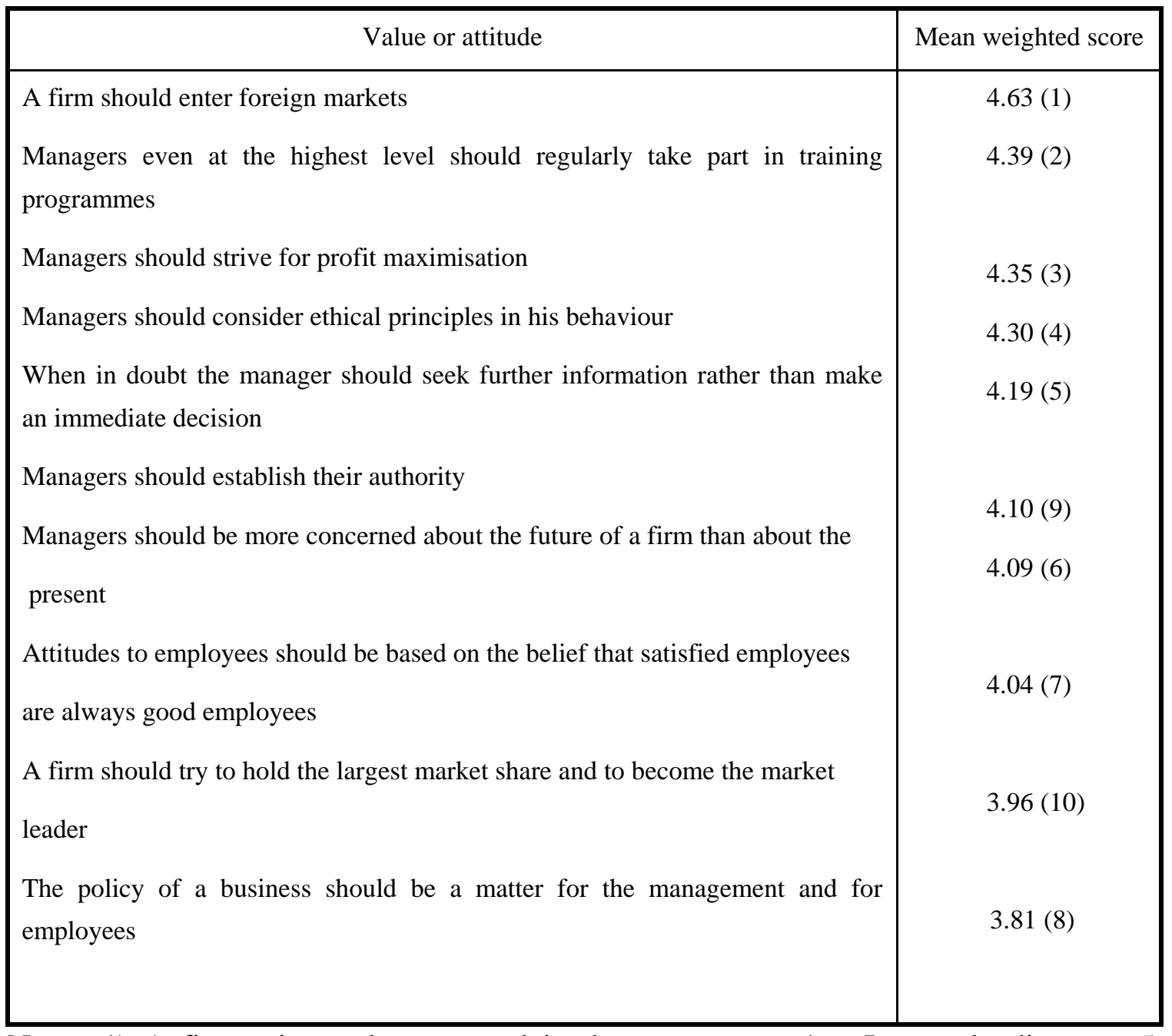

Notes: 1) A five point scale was used in the assessment: $1=\mathrm{I}$ strongly disagree, $5=\mathrm{I}$ strongly agree

2) In the brackets there are ranks assigned to an individual value or attitude in the 1994 research

$96.3 \%$ of enterprises from the sample have some export sales today. A vast majority (84.2\%) of enterprises have at least 7 and more years of experience in the field of exporting. 55.4\% of enterprises created more than one half of their turnover by exporting in 1995, 54.8\% in 1994, and $66.0 \%$ in 1993 . It seems that there has been some shift away from the implementation of an export expansion 
strategy after 1993 among Slovenian enterprises. This change in the strategic behaviour could be the result of the exchange rate policy on the one hand, and of the dynamic growth of domestic consumption and other influential external strategic factors on the other.

Table 4: Shares of sales on domestic market in 1990, 1993, and 1995

\begin{tabular}{|l|c|c|c|}
\hline Sales share & Year 1990* & Year 1993 & Year 1995 \\
\hline up to 10\% & 3.4 & 11.1 & 13.9 \\
above 10-30\% & 13.6 & 31.9 & 33.3 \\
above 30-50\% & 15.3 & 27.8 & 23.6 \\
above 50-70\% & 20.3 & 15.3 & 20.8 \\
above 70-90\% & 30.5 & 9.7 & 5.6 \\
above 90\% & 16.9 & 4.2 & 2.8 \\
\hline Total & 100.0 & 100.0 & 100.0 \\
\hline
\end{tabular}

* Results of the research implemented in 1994

"A strive for profit maximization" is also a very significant value (See Table 3). Slovenian managers place much more emphasis on profit maximization than their western counterparts. We can see this from the export sales profit margin reached by Slovenian enterprises. It can be concluded that the restructuring of the sales markets of Slovenian firms has diminished their sales profit margins. Enterprises have not been able to improve the levels of these margins after 1993, on the contrary they have been confronted with some further slight change for the worse. (See Table 5.) Unfavourable factors in the macro environment and stagnation of strategic restructuring of enterprises could be possible reasons for these results.

Table 5: Profit margin, achieved on foreign (hard currency) markets in 1990, 1993, and 1995

\begin{tabular}{|l|c|c|c|}
\hline $\begin{array}{l}\text { Level of the profit } \\
\text { margin }\end{array}$ & Year 1990* & Year 1993* & Year 1995 \\
\hline no profit margin & 12.2 & 24.6 & 37.6 \\
minimal margin & 15.1 & 33.3 & 24.7 \\
modest margin & 24.2 & 42.1 & 32.5 \\
good margin & 45.5 & - & 5.2 \\
unknown & 3.0 & - & - \\
\hline
\end{tabular}




\begin{tabular}{|l|l|l|l|}
\hline Total & 100.0 & 100.0 & 100.0 \\
\hline
\end{tabular}

* Results of the research, implemented in 1994

In spite of this fact Slovenian enterprises have been implementing the strategy of entering new foreign markets (72.5\% of enterprises) and of sales increase on foreign markets (71.3\% of enterprises). The strategy of sales enlargement on domestic market is only the third most usually implemented one $(51.3 \%$ of enterprises).

The results of STRATOS group show that managers in smaller countries are likely to avoid change (mean weighted score 2.19) and that managers in larger countries tend to be more open to change than those in smaller countries. Managers in larger countries are more interested in cooperation. They even want to co-operate with very large companies and grow even in foreign markets (The STRATOS Group, 1990, p.31).

We could not find any empirical evidence in the case of Slovenia for such conclusions. On the contrary, our empirical results show many differences in personal values and attitudes of Slovenian managers when compared with the value orientation of Western European managers. Slovenian managers are more open to changes than their Western European counterparts. They have been exposed to many turbulent changes in the process of transition and they deal with changes as with any usual procedure. They assigned to the value " Changes in a business should be avoided at all costs" the lowest rank which is even below the score of the Western European managers (See Table 6).

They are also more prepared to use different forms of subcontracting activities. Western European managers in small countries assigned mean-weighted score 3.17 to the value "Firms should co-operate with other firms to be effective even at the expense of some independence" (The STRATOS Group, 1990, p.31). In our 1994 research (Pucko, 1995, No.1-2: 27) we came to an important conclusion, namely, that many Slovenian enterprises applied some kind of a subcontracting strategy during the first three years of transition. In the 1991 1993 period $39.6 \%$ of enterprises started to build subcontracting relationships. In the last three year period $27.5 \%$ of firms have started some new subcontracting (most, i.e. 81,8\% of them, with foreign partners). On the other hand, only $5 \%$ of firms abandoned such relationships during the same period. $28.8 \%$ of Slovenian subcontractors increased the number of their partners. 30\% of them increased the number of products that were the objects of their subcontracting relationships. Only $17.5 \%$ of enterprises reduced the number of customers in their subcontracting relationships. A relatively small number of firms (12.5\%) diminished the number of products under the subcontracting terms.

In fact Stratos research shows that $41.4 \%$ of firms in Western European countries (those which were included in the research) use some form of 
subcontracting activities. The Stratos research confirms the opinion that larger countries, and the markets associated with them, offer more favourable conditions for subcontracting compared with smaller countries.

Table 6: The less acceptable personal values and attitudes held by top Slovene managers

\begin{tabular}{|l|c|}
\hline \multicolumn{1}{|c|}{ Value or attitude } & Mean weighted score \\
\hline Changes in a business should be avoided at all costs & 1.69 (1) \\
\hline Management is man' s work & $1.74(3)$ \\
\hline The manager should co-ordinate all tasks and activities himself & 2.01 (7) \\
\hline Innovation involves too much risk & 2.03 (9) \\
\hline Firms should only introduce proven office procedures and & $2.10(16)$ \\
\hline production techniques & 2.13 (2) \\
\hline Managers should criticise poor work by employees before their colleagues & $2.14(13-14)$ \\
\hline Managers should only rely on their intuition when making decisions & \\
\hline A firm should start from the principle of equal pay for equal work even & \\
\hline if this raises costs & 2.15 (6) \\
\hline A firm should plan in detail even at the risk of losing flexibility & \\
\hline
\end{tabular}

Notes: 1) A five point scale was used in the assessment: $1=\mathrm{I}$ strongly disagree, $5=\mathrm{I}$ strongly agree

2) In the brackets there are ranks assigned to an individual value or attitude in the 1994 research

We have established that $44.9 \%$ of Slovenian firms are implementing some sort of a subcontracting strategy nowadays. Three thirds of them create more than $20 \%$ of their total turnover by subcontracting. Nearly one quarter of enterprises create more than one half of their total sales by subcontracting. All these findings show that subcontracting strategies have been extraordinary important kinds of strategy for Slovenian business firms after Slovenia was established as an independent state. This strategic orientation of Slovenian enterprises has been apparently chosen as a way of integrating Slovenian manufacturing firms into the European economy.

\section{Objectives of top managers and of the Slovenian enterprises}

The personal objectives of the managing directors of Slovenian "old" enterprises appear to match quite well with the personal objectives of the Western European entrepreneurs and managers. On the other hand, some slight changes to the personal objectives of top Slovene management, during the early 
stage of transition (first 3 years) and during the second stage (the last two years) may be identified (See Table 7).

Western European managers appreciate least "high social status" (2.14) and "playing a role in society" (2.49). Respondents in Western Europe attach very little importance to everything that is primarily society oriented (The STRATOS Group, 1990, p.52). On the basis of our empirical findings the same could be concluded for the Slovenian managers.

Table 7: The individual objectives of top managers, ranke by importance

\begin{tabular}{|c|c|c|c|}
\hline Rank & Individual objective & $\begin{array}{c}\text { Mean weighted } \\
\text { score } \\
\text { (Slovenia) }\end{array}$ & $\begin{array}{c}\text { Mean weighted } \\
\text { score } \\
\text { (Stratos) }\end{array}$ \\
\hline 1 & Making good products & $4.64(1)$ & $4.52(1)$ \\
\hline 2 & Job satisfaction & $4.56(2)$ & $4.29(2)$ \\
\hline 3 & Financial independence for you and your family & $4.09(3)$ & $4.02(4)$ \\
\hline 4 & Doing better than other businessmen & $4.06(5)$ & $3.15(8)$ \\
\hline 5 & Selfactualisation & $3.88(4)$ & $3.97(5)$ \\
\hline 6 & High level of income & $3.78(6)$ & $3.15(7)$ \\
\hline 7 & Meeting people & $3.73(7)$ & $3.85(6)$ \\
\hline 8 & Influence & $3.48(9)$ & $2.71(11)$ \\
\hline 9 & Personal independence & $3.41(8)$ & $4.08(3)$ \\
\hline 10 & High social status & $3.2610)$ & $2.14(14)$ \\
\hline 11 & Attractive life-style & 3.15 (11) & $2.80(10)$ \\
\hline 12 & Playing a role in society & 3.15 (12) & $2.49(12)$ \\
\hline
\end{tabular}

Note: 1) A five points scale was used in the assessment: $1=$ no importance $5=$ very high importance

2) In the brackets of Slovenian research there are ranks assigned to an individual value or attitude in the 1994 research

3) In the brackets in Stratos research there are ranks assigned to an individual value or attitude according to the Stratos research.

The top Slovenian managers consider their objectives as employers (See Table 8) in almost the same way as their Western European counterparts (Compare with the STRATOS Group results). Both groups of businessmen evaluate as the most important the first four objectives stated in Table 8. They even assigned similar mean-weighted scores to them. The top Slovenian managers considered the last four ranked objectives in the Table 5 to be much more important than their Western European counterparts did. 
The objectives of Slovenian businesses appear to be pretty stable during the transition period. They are quite similar to the most important objectives of Western European business firms. Among the ten most important objectives eight of them are equal. Both groups of managers consider quality as the most important strategic objective and that certainly reflects the current world's trend. Slovenian managers emphasized the necessity of cost reduction more than Western European managers did what is no doubt related to the strategic restructuring process of the Slovenian economy.

Table 8: The top managers' objectives as employers

\begin{tabular}{|l|c|c|}
\hline \multicolumn{1}{|c|}{ Objective } & $\begin{array}{c}\text { Mean weighted score } \\
\text { (Slovenia) }\end{array}$ & $\begin{array}{c}\text { Mean weighted score } \\
\text { (Stratos) }\end{array}$ \\
\hline Good working conditions & $4.19(1)$ & $4.01(1)$ \\
Saving jobs & $3.98(2)$ & $3.82(2)$ \\
Self-fulfilment & $3.86(5)$ & $3.69(3)$ \\
Improving my employees' life style & $3.83(4)$ & $3.42(4)$ \\
Profit sharing & $3.47(3)$ & $2.39(7)$ \\
Participation of employees in ownership & $3.41(7)$ & $2.96(6)$ \\
Job creation & $3.30(6)$ & $2.98(5)$ \\
Participation of employees in decision-making & $3.11(8)$ & $1.78(8)$ \\
\hline
\end{tabular}

Note: 1) A five point scale was used in the assessment: $1=$ no importance, $5=$ very high importance

2) In the brackets there are ranks assigned to an individual value or attitude in the 1994 research

3) In the brackets in Stratos reesearch there are ranks assigned to an individual value or attitude according to the Stratos research.

\section{Business strategies of Slovenian enterprises}

The essence of a business strategy is linked to the definition of how a strategic business unit can achieve its competitive advantage (Porter, 1985: 11). There could be many strategic factors for achieving a competitive advantage. Let us look into the factors that are considered to be the most important for providing a competitive advantage for strategic product groups of Slovenian enterprises on their main market! Managing directors or top management assessed the importance of 26 factors by assigning to each of them different weights ( $1=$ no importance, $2=$ little importance, $3=$ medium importance, $4=$ great importance, and $5=$ very great importance). If we multiply the number of assessments of each category with the appropriate weight, we are able to compute the average weighted assessment for each factor. This average weighted assessment enables 
us to identify the most important factors, which determine a competitive advantage. Those factors have been computed for Slovenian enterprises and are shown in Table 10.

Table 9: The most important strategic objectives of the Slovenian "old" business firms in the 1996 and Western European enterprises

\begin{tabular}{|l|c|c|}
\hline \multicolumn{1}{|c|}{ Objective } & $\begin{array}{c}\text { Mean weighted score } \\
\text { (Slovenia) }\end{array}$ & $\begin{array}{c}\text { Mean weighted score } \\
\text { (Stratos) }\end{array}$ \\
\hline 1. Product quality & $4.84(1)$ & $4.48(1)$ \\
2. Cost reduction & $4.65(2)$ & $4.06(9)$ \\
3. Good liquidity & $4.56(4)$ & $4.31(3)$ \\
4. Productivity & $4.54(3)$ & $4.21(4)$ \\
5. Profit & $4.48(5)$ & $4.04(10)$ \\
6-7. Creativity and innovations & $4.40(7)$ & $4.12(7)$ \\
6-7. Flexibility & $4.40(8)$ & $4.18(5)$ \\
8. Financial independence & $4.28(6)$ & $4.13(6)$ \\
9. Market share & $4.25(9)$ & $3.66(12)$ \\
10. Economic authonomy & $4.17(12)$ & $3.81(11)$ \\
11. Company image & $4.15(10)$ & $4.07(8)$ \\
12. Growth & $4.06(11)$ & $3.60(13)$ \\
\hline
\end{tabular}

Note: 1) A five point scale was used in the assessment: $1=$ no importance, $5=$ very high importance

2) In the brackets there are ranks assigned to an individual value or attitude in the 1994 research

3) In the brackets in Stratos research there are ranks assigned to an individual value or attitude according to the Stratos research.

Links between the Slovenian firms' objectives and the top managers' personal objectives on one hand and, on the other hand, links between them and the top managers' ranking of the factors of the competitive advantage apparently exist, too (see Table 10). The roots of competitive advantages in Slovenia are, according to both research projects, quite similar to those in Western European countries. Slovenian managers attribute more importance to low costs and less importance to firm's reputation than their Western European counterparts but otherwise we may identify many similarities.

Most Slovenian enterprises implement a niche strategy (53\%) on their market. One quarter of firms apply a product differentiation strategy. The cost leadership strategy is implemented by one fifth of Slovenian firms. As niche 
strategies can be theoretically directed on product differentiation or low cost, we should find out how these two strategic options are applied in Slovenian firms.

Table 10: Most important factors determining competitive advantage of enterprises

\begin{tabular}{|l|c|c|}
\hline \multicolumn{1}{|c|}{ Factor } & $\begin{array}{c}\text { Mean weighted score } \\
\text { (Slovenia) }\end{array}$ & $\begin{array}{c}\text { Mean weighted score } \\
\text { (Stratos) }\end{array}$ \\
\hline 1. Product quality & $4.70(1)$ & $4.53(1)$ \\
2. Reliability of supply & $4.47(3)$ & $4.41(2)$ \\
3. Low costs & $4,42(4)$ & $3,81(11)$ \\
4. Management quality & $4.40(\ldots)$ & $4.09(6)$ \\
5. Flexibility & $4,34(6)$ & $4,14(5)$ \\
6. Skills & $4,31(\ldots)$ & $4.22(4)$ \\
7. Trademark & $4.21(10-13)$ & $3.74(13)$ \\
8. Firm's reputation & $4.17(\ldots)$ & $4.30(3)$ \\
9. Creativity & $4.12(\ldots)$ & $3.80(12)$ \\
10 - 11. Pricing policy & $4.10(2)$ & $3.64(16)$ \\
10 - 11. Terms of payment & $4.10(\ldots)$ & $3.67(15)$ \\
12. Availability of financial resources & $4.04(\ldots)$ & $3.96(8)$ \\
\hline
\end{tabular}

Note: 1) A five point scale was used in the assessment: $1=$ no importance, $5=$ very high importance

2) In the brackets there are ranks assigned to an individual value or attitude in the 1994 research

3) In the brackets in Stratos research there are ranks assigned to an individual value or attitude according to the Stratos research.

Main factors influencing the achievement of competitive advantage, shown in Table 10, give some ground for the conclusion that the product differentiation strategic orientation dominates in Slovenian firms. The product differentiation strategy (Porter, 1980: 38) requires a high product quality, reliability of supplies, well developed and known trademarks, good company reputation, creativity, and other distinguished characteristics of behaviour. Table 10 shows that Slovenian firms build their strategic behaviour along these lines. The product differentiation strategy could focus on a market segment or aim at the whole market. The first orientation is known as a market niche strategy based on product differentiation, the second as a product differentiation. It seems that both of the above mentioned strategic orientations are the most frequently present in the strategic behaviour of Slovenian enterprises. 
The collected answers to our questionnaire do not allow us to derive very firm conclusions regarding the role that the cost leadership strategy has among different kinds of business strategy in Slovenian enterprises. According to a modest evidence this kind of strategy has not been in use as frequently as the other kinds. On the other hand we can not be quite sure that enterprises really implement a definite kind of generic business strategy in spite of the fact that they have declared so. There could still be a lot of cases of companies stuck somewhere in the middle (Porter, 1985: 16-17).

Figure 1: How successful is your firm

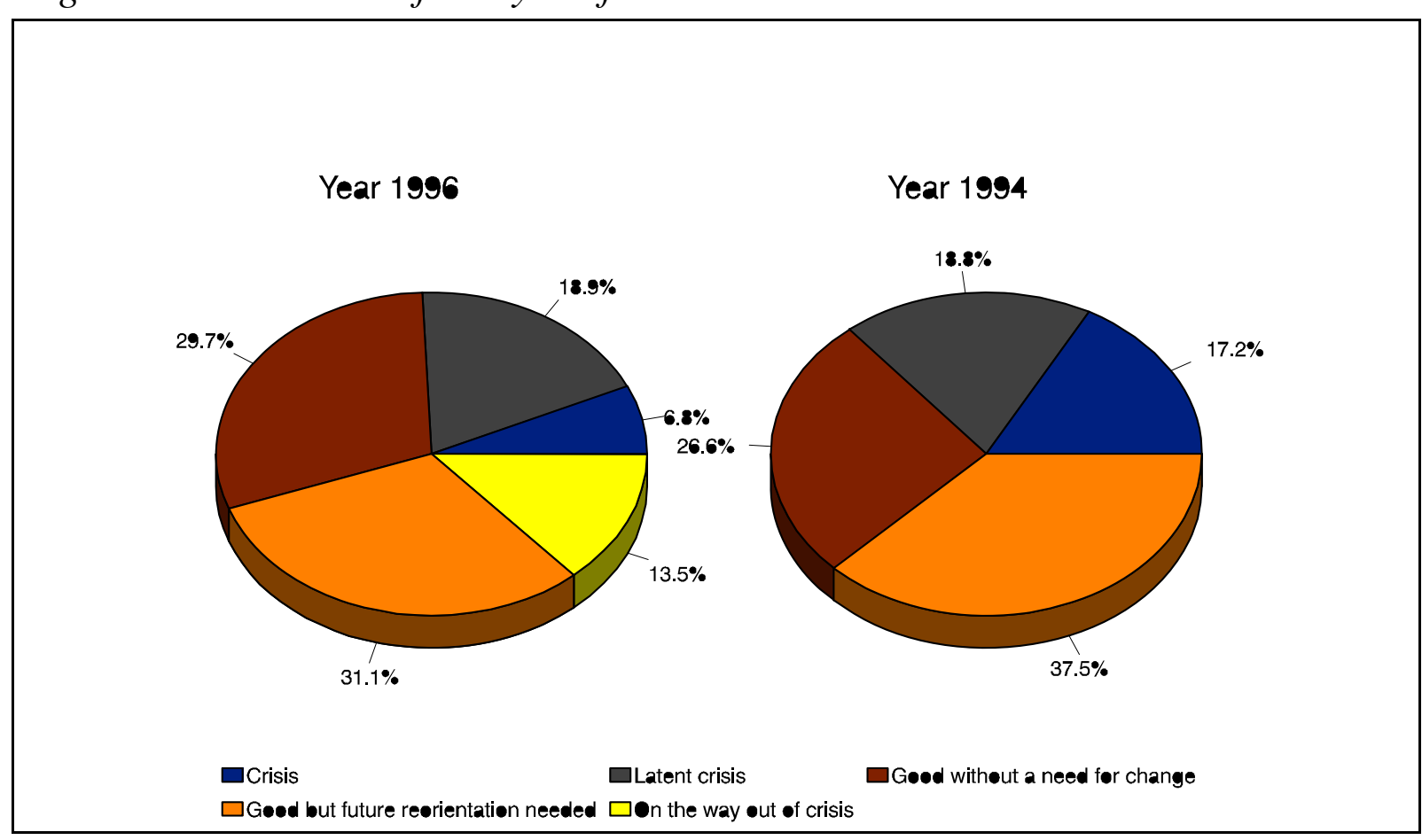

\section{Where are we and how long will the process of strategic restructuring take in Slovenian enterprises?}

By comparing the assessments of stages in which an individual enterprise is today or was in 1994, we can come to a conclusion that certain positive results in the processes of company strategic restructuring have been achieved in the last two years. As Figure 1 shows only $6.8 \%$ of enterprises are confronted with an acute situation of crisis today. There were $17.2 \%$ of enterprises in such a situation in 1994. $13.5 \%$ of enterprises are still in a state of a latent crisis (Krystek, 1981: 29 and 31) compared to 18.8\% in 1994. These indicators show an evident improvement in the general circumstances in the relevant industries. On the other hand they warn us that the processes of strategic restructuring of enterprises will not be terminated soon.

$13.8 \%$ of managing directors have predicted that the process of strategic restructuring of their firms would be completed in the current year. One third of 
managing directors $(32.5 \%)$ predicted that they would need at least two additional years for the completion of the restructuring process. $16.3 \%$ of enterprises will most probably need between two and four years for their restructuring. According to predictions $17.5 \%$ of firms will need a period that will span over four additional years. The rest have already completed their strategic restructuring process or they (6.3\% of firms) have had no necessity for it.

The managing directors' satisfaction with their company profits earned in 1990, 1993, and 1995 differs. By comparing 1993 and 1995, we see that a slightly higher number of firms achieved better results in the latter year. The profitability level achieved in 1995 is also slightly better than the one achieved in 1993 (See Table 11). These indicators are additionally strong arguments and support the thesis that "old" Slovenian manufacturing enterprises enjoyed some important positive results when implementing the processes of strategic restructuring.

Table 11: Satisfaction with profit and profitability levels in Slovenian enterprises in 1993 and 1995

\begin{tabular}{|l|c|c|}
\hline $\begin{array}{l}\text { Degree of satisfaction with } \\
\text { profit : }\end{array}$ & $\begin{array}{c}\text { Year 1993 } \\
\text { (\% of firms) }\end{array}$ & $\begin{array}{c}\text { Year 1995 } \\
\text { (\% of firms) }\end{array}$ \\
\hline - more satisfied & 42.9 & 45.4 \\
- less satisfied & 41.2 & 39.0 \\
- equally satisfied & 15.9 & 15.6 \\
\hline TOTAL & 100.0 & 100.0 \\
\hline Profitability rate: & 26.3 & 25.7 \\
\hline - negative & 59.0 & 51.3 \\
- between 0 and 6\% & 11.5 & 16.2 \\
- above 6 - 12\% & 1.6 & 4.1 \\
- above 12\% - 20\% & 1.6 & 2.7 \\
\hline - above 20\% & 100.0 & 100.0 \\
\hline TOTAL & & \\
\hline
\end{tabular}

The process of privatisation of the previously socially owned enterprises, which has been going on intensely since 1995, could be another factor that will contribute to a further improvement in the performance level of every privatised company in the near future. $48.8 \%$ of managing directors (or members of top management teams) are convinced this correlation is rather high or even 
extraordinary. Less than a quarter of respondents (22.5\%) consider this correlation low or even non-existent.

\section{Conclusion}

Slovenia established a democratic political system in 1990 and it became a new, independent European state in 1991 when the Socialist Republic of Yugoslavia split apart. Slovenian businesses lost a relatively huge domestic market as a result of all these changes. The transition in Slovenia has been going on for six years. In more than two thirds of the Slovenian enterprises the restructuring processes are not completed yet.

The changes on the positions of managing directors in the firms, carried out in the transition period, seem to be appropriate and logical enough if we compare them with findings about relevant changes in the implementation of radical turnaround strategies in companies elsewhere in the world. Slovenian managing directors perceive their key strategic tasks in the second stage of the enterprise restructuring process mostly in the way that could lead to improved performance of the enterprises.

A value system of the Slovenian managers still differs quite significantly from the value system of Western European managers. We try to explain this with some economic and political factors. Slovenian managers have been exposed to many drastic changes in their economic and political environment in recent years and they are still more open to changes than their Western European counterparts. During the transition period many enterprises have chosen and started to implement some kinds of subcontracting strategy. At least one quarter of enterprises are vitally dependent on subcontracting now. In the majority of cases subcontracting relationships have been established with Western European business firms. It means that a strong integrative link between the Slovenian economy and the economy of the European Union has already been developed.

On the other hand a comparison of the personal objectives of the managing directors and their objectives as employers appear to match quite well with those of the Western European managers. The objectives of Slovenian businesses are quite stable during the transition period and are similar to the most important objectives of Western European businesses.

Factors of the competitive advantages in Slovenian firms are also similar to those in Western European firms. Most Slovenian firms implement a niche strategy, a product- differentiation strategy is used by one quarter of Slovenian firms, and the cost leadership strategy is implemented by one fifth of Slovenian firms. We may assume that many firms are in Porter's sense "stuck somewhere in the middle". 
Two thirds of Slovenian managers predict that their firm would need at least two years or more for strategic restructuring. An important weakness in "old" Slovenian firms, especially in the last two years, is linked with the preoccupation of top management teams with the issue of company privatisation. It has caused some stagnation in solving other important strategic issues. We can just hope that this weakness is more or less surpassed now, as privatisation programmes of the majority of enterprises have been already approved. On the other hand, privatisation has to contribute additionally to the increase in company performance levels in the near future.

\section{References}

Brilmann, J. (1986): Géstion de crise et redressement d'entreprises, Éditions Hommes et Téchniques, Paris

Goold, M. (1996): Parenting Strategies for the Mature Business, in Long Range Planning, No.3.

Kilmann, R.H./ Covin, J.T. and Associates (1988): Corporate Transformations, Jossey-Bass Publishers, London

Krystek, U. (1981): Krisenbewaltigungsmanagement und Unternehmungsplanung, Gabler, Wiesbaden

Porter, M.E. (1980): Competitive Strategy, The Free Press, London

Porter, M.E. (1985): Competitive Advantage, The Free Press, London

Pucko, D. (1995): Strateško preoblikovanje podjetij: slovenske izkušnje, in: Slovenska ekonomska revija, No.1-2

Pucko, D. (1995): Strateško preoblikovanje podjetij - kljuèna spoznanja, in: Naše gospodarstvo, No.5-6.

Regionalna struktura prodaj, nabav, terjatev do kupcev in obveznosti do dobaviteljev gospodarstva Republike Slovenije po korigiranih podatkih o kuporodajah in drugih finanènih razmerjih za obdobje 1.1. do 31.12. 1990, Zavod Republike Slovenije za druzbeno planiranje, Ljubljana, 7.5.1991.

The STRATOS Group (1990): Strategic Orientations of Small European Businesses, Gower publishing company, Aldershot. 